This is a pre-publication version of a paper forthcoming in the Journal of Southern African Studies. A previous version was published as a working paper at the Centre for Social Science Research at the University of Cape Town. Please refer to the final published version for citation purposes.

Final information will be available at http://kevinpdonovan.com/other-writing/

\title{
The Biometric Imaginary: Bureaucratic Technopolitics in Post-Apartheid Welfare*
}

Kevin P. Donovan

(Programs in Anthropology \& History and Science, Technology \& Society, University of Michigan)

Starting in March 2012, the South African government engaged in a massive effort of citizen registration that continued for more than a year. Nearly 19 million social welfare beneficiaries enrolled in a novel biometric identification scheme that uses fingerprints and voice recognition to authenticate social grant recipients. This paper seeks to understand the meaning of biometric technology in post-apartheid South African welfare through a study of the bureaucratic and policy elite's motivation for this undertaking. It suggests that biometric technology was conceived of and implemented as the most recent in a series of institutional, infrastructural, and policy reforms that seek to deliver welfare in a standardised and objective manner. This commitment to standardisation and objectivity has, at times, been driven by a false faith in technical efficacy and a downplaying of the political implications of biometric welfare identification.

\section{Introduction: The Biometric Imaginary in Post-Apartheid Welfare}

Beginning in March 2012 and continuing for about a year and a half, 18.9 million predominantly low-income South African residents queued at government facilities to be photographed and submit their personal details, including a full set of fingerprints and a voice recording. ${ }^{1}$ From rural towns to major cities, old and young alike were required to present themselves for this massive registration drive initiatied by welfare policymakers implementing a new administrative infrastructure for South Africa's extensive program of social grants. This redistribution has deep roots, with formal welfare beginning in the 1920s as an effort to curtail poverty within the white population. ${ }^{2}$ In subsequent decades, it expanded considerably and

\footnotetext{
${ }^{*}$ This work benefited considerably from comments and guidance by Jeremy Seekings, Keith Breckenridge, Paul Edwards, Aaron Martin and the African History \& Anthropology Workshop at the University of Michigan. I'm grateful for additional assistance from Jonathan Donner, Marion Walton, Francis Nyamnjoh, Charles Weiss, and Mike Nelson. A Fulbright Fellowship, the Institute for Money, Technology, and Financial Inclusion at UC Irvine, and Privacy International provided crucial financial support. My appreciation to all.

${ }^{1}$ SASSA, Annual Report 2012/2013 (Pretoria, South African Social Security Agency, 2013).

2 J. Seekings, "Not a Single White Person Should be Allowed to Go Under": Swartgevaar and the Origins of South Africa's Welfare State, 1924-1929', Journal of African History, 48 (2007), pp. 375-394.
} 
today these grants to the elderly, poor caregivers, and the disabled are perhaps the most significant means of poverty alleviation. ${ }^{3}$

Despite this, the politics of welfare in South Africa are contentious. ${ }^{4}$ While proponents tend to be motivated by apartheid's legacy of poverty and inequality and draw on the protections of the Constitution, there is also a strand of support that promotes grants as a means to escape a poverty trap, allowing the poor to enter the market as entrepreneurial risktakers. ${ }^{5}$ In contrast, opponents tend to worry about the cost of the grants, the risk of welfare dependency, and perverse incentives. ${ }^{6}$

Those 19 million residents - nearly 40 percent of the country's entire population provided their personal details in order to receive their grants through a new payment system. For the government, the system promised a reliable means of delivering millions of rand per month. As the Minister of Social Development Bathabile Dlamini would explain, the goal was 'to improve the integrity of our social security system, and to eliminate all forms of fraud and corruption. ${ }^{7}$ Prominent civil society organisations like the Black Sash, too, 'welcomed [the] move to a biometric system'. ${ }^{8}$ The new system aimed to offer increased convenience through

\footnotetext{
${ }^{3}$ On the grants as a type of 'redistributive economy,' see E. Bähre, 'Liberation \& Redistribution: Social Grants, Commercial Insurance, and Religious Riches in South Africa', Comparative Studies in Society \& History, 52, 2 (2011), pp. 371-392.

${ }^{4}$ D. Everatt, 'The Undeserving Poor: Poverty and the Politics of Service Delivery in the Poorest Nodes of South Africa', Politikon, 35, 3 (2008).

${ }^{5}$ J. Ferguson, 'The Uses of Neoliberalism', Antipode, 41, S1 (2010), pp. 166-184. Additionally, in the case of COSATU, whose members stand to gain through the defense of high wages, a relaxed need to support poor dependents, and an expansion of state administration, there is also a measure of self-interest. On this see, J. Seekings and H. Matisonn, 'The Politics of the Basic Income Grant in South Africa. 1996-2002', in G. Standing and M. Samson (eds) The Basic Income Grant in South Africa (Cape Town, University of Cape Town Press, 2003), pp. 56-76.

${ }^{6}$ C. Meth, 'Ideology and Social Policy: "Handouts" and the Spectre of "Dependency", Transformation, 56, 1 (2004), pp. 1-30. F. Barchiesi, Precarious Liberation: Workers, the State, and Contested Social Citizenship in Post-Apartheid South Africa (Albany, NY, SUNY Press, 2011).

${ }^{7}$ B. Dlamini, 'Statement by the Minister of Social Development, Bathabile Dlamini, on the Occasion of SASSA Media Briefing', Department of Social Development (March 2013), available at http://allafrica.com/stories/201303261051.html?viewall=1, retrieved on 6 February 2014.

${ }^{8}$ N. Nyembezi, 'Poor Fear Social Grant Cut-offs During Biometric System Switchover', Black Sash (April 2012), available at http://goo.gl/jtfOIR, retrieved on 6 February 2014.
} 
the provision of a payment card accepted at a large cash distribution network established by the government's contractor, Net1 CPS. ${ }^{9}$

The cornerstone of this new system is biometric identification, the use of technologies to recognise specific bodily features. A fingerprint would be the primary means of authenticating recipients, but in case a fingerprint scanner was unavailable, the grant recipients also provided a voice recording, to serve as a back-up means of verifying individuals at the time of payment. This is not the first time biometric identification has been used widely in South Africa. Both before and during apartheid, government officials were enamored of the potential for using analog fingerprinting to identify individuals, most commonly in schemes of racial labor control. ${ }^{10}$ In the post-apartheid era, digital biometric technology has been central to the identification programs of the Department of Home Affairs, as well as used extensively in previous welfare systems.

Yet rarely have these systems functioned as promised, whether for good or ill. ${ }^{11}$ Therefore, the continuing salience of biometric identification amongst the bureaucratic and policy elite seems curious. To explain this 'non-scandal,' this paper narrates the post-apartheid history of welfare state building that culminated in the 2012-2013 biometric registration drive. To do so, I rely primarily on an archive of government documents, civil society reports, court filings, parliamentary minutes, and nearly a dozen interviews with stakeholders. I pay particular attention to the ways in which elites - especially those within welfare bureaucracies and their interlocutors on supervisory panels and commissions - conceptualise and attach meaning to biometric identification. I explicate the reasons for which it is adopted by

\footnotetext{
${ }^{9}$ As in other areas of South African government, the role of private contractors has crucially reshaped this terrain of service provision.

10 For the longer history, see K. Breckenridge, Biometric State: The Global Politics of Identification and Surveillance in South Africa, 1850 to the Present (Cambridge, Cambridge University Press, 2014).

${ }^{11}$ On the historical shortcomings, see I. Evans, Bureaucracy and Race: Native Administration in South Africa (Berkeley, CA, University of California Press, 1997), p. 99; K. Breckenridge, 'Verwoerd's Bureau of Proof: Total Information in the Making of Apartheid', History Workshop Journal, 59, 1 (2005), pp. 83-108; and K. Breckenridge, 'The Elusive Panopticon: The HANIS Project and the Politics of Standards in South Africa', in C.
} 
policymakers and members of government, especially those within the welfare administration who face the twin tasks of streamlining delivery while tightening access.

Historians have suggested that states and societies tend to cohere particular systems for registering and identifying individuals. 'Viewed globally,' write Szreter and Breckenridge, 'societies, and the individuals within them, seem to be very variably shaped by what we might call cultures of registration'. ${ }^{12}$ Similarly, Caplan suggests that a 'culture of identification' 'essentially unruly' but comparatively distinct - can be said to exist in a given society. ${ }^{13}$

In this paper I aim to explicate some of the dynamics behind a post-apartheid culture of registration and identification. I argue that a relatively stable and collective understanding exists among the bureaucratic and policy elite about how to constitute the relationship between the welfare state and beneficiary. In brief, this collective understanding - that I propose to call the biometric imaginary - posits biometric technology as a necessary, suitable, and effective means of constructing a standardised and objective welfare state. This paper traces the emergence, spread, and influence of this imaginary.

The will to standardise has arisen as a means of uniting and improving the fragmented and weak bureaucracy inherited from the apartheid regime. South Africa has endeavoured to create equality of citizenship through imposing uniformity. This has included bureaucratic centralisation (first through the establishment of a unitary, national Department of Social Development (DSD) in 1994, and after through the creation of the South African Social Security Agency (SASSA) in 2005) as well as technological reform (such as through the linking of various databases and implementation of new payment infrastructures).

Bennett and D. Lyon (eds) Playing the Identity Card: Surveillance, Security and Identification in Global Perspective (London, Routledge, 2008), pp. 39-56.

${ }^{12}$ S. Szreter and K. Breckenridge, 'Editor's Introduction: Recognition and Registration: The Infrastructure of Personhood in World History', in K. Breckenridge and S. Szreter (eds) Registration \& Recognition: Documenting the Person in World History (Oxford University Press, 2012), p. 3. 
In parallel, an egalitarian ethos has militated against subjectivity, in favour of rulebound practices. In democratic South Africa, subjective discretion has been viewed with suspicion as the state has sought to create equality of citizenship. In the realm of welfare, two forms of discretion have proven particularly troubling: illicit access to grants and bureaucratic error. A preference for objective practice has deeply influenced the social grants, with biometric identification offering an impersonal and presumptively neutral means of grant administration, aligning with a parallel discourse of widespread fraudulent access to the grants.

Both standardisation and objectivity are widespread and productive - though not hegemonic - commitments that shape the understanding of biometric registration and identification. This particular confluence of the will to standardise, the pursuit of objectivity, and the use of social grants has given rise to the belief that biometric identification is necessary, suitable, and effective. As in Appadurai's discussions of social imaginaries, the biometric imaginary is 'a constructed landscape of collective aspirations' that serves as a 'staging ground for action'. ${ }^{14}$ These imaginaries are productive social forces with real-world implications, but they do not always accurately correspond to reality, exhibiting varying degrees of interpretive flexibility. As I will contend, the dominant understanding of biometrics as necessary, suitable, and effective are each, in part, fantasy and reality.

The biometric imaginary reflects the culture of registration and identification insofar as it is a shared set of understandings with attendant practices and politics; yet it is not merely relevant at the level of ideas; it has material enablers and effects. Biometric welfare is a form of 'technopolitics', Hecht's term for the 'strategic practice of designing or using technology to

\footnotetext{
${ }^{13}$ J. Caplan, “"This or That Particular Person": Protocols of Identity in Nineteenth-Century Europe', in J. Caplan and J. Torpey (eds) Documenting Individual Identity: The Development of State Practices in the Modern World (Princeton University Press, 2001), p. 51.

${ }^{14}$ A. Appadurai, Modernity at Large: Cultural Dimensions of Globalization (Minneapolis, University of Minnesota Press, 1996), p. 31.
} 
constitute, embody, or enact political goals.' ${ }^{15}$ The will to standardise and the pursuit of objectivity have driven a series of technopolitical programs within the post-apartheid welfare sector, including institutional centralisation, technological standardisation, and bureaucratic automation.

Here, 'post-apartheid' does not mark a total rupture with apartheid's bureaucratic logics, but rather signifies the redirected emphasis. For at least two decades, biometric technology has been harnessed toward redistributive welfare rather than apartheid-era controls. In this, the 2012 SASSA contract with Netl CPS is an unprecedented moment: a nationally centralised database of 19 million grant beneficiaries who are biometrically identified for each payment. The emulation of both South Africa's system of social grants ${ }^{16}$ and biometric methodologies ${ }^{17}$ suggests the need for an understanding of the conceptualisation, meaning, and drivers of biometric welfare in South Africa.

This paper next turns to the drivers of standardisation and objectivity before showing how - and with what consequences - biometrics have been used to reach those goals. Section two analyzes the institutional and political history of the post-apartheid welfare state; in particular, it traces the emergence of a desire for uniform policy that led to the centralization of welfare bureaucracies. Section three turns more directly to practice, examining how discourses of 'corrupt' bureaucrats and 'fraudulent' recipients have fueled the adoption of biometric identification. Together, these two sections excavate the commitments underlying the biometric imaginary while the closing sections adopt a more critical posture.

\footnotetext{
${ }^{15}$ G. Hecht, The Radiance of France: Nuclear Power and National Identity after World War II ( $2^{\text {nd }}$ edition, Cambridge, MA, MIT Press, 2009 [1998]), p. 15.

${ }^{16}$ J. Hanlon, A. Barrientos, and D. Hulme, Just Give Money to the Poor: The Development Revolution from the Global South (Kumarian Press, 2010).

${ }^{17}$ A. Gelb and J. Clark, 'Cash at Your Fingerprints: Biometric Technology for Transfers in Developing and Resource-Rich Countries', CGD Working Paper 253, Washington, D.C. and K. Breckenridge, 'The World's First Biometric Money: Ghana's e-Zwich and the Contemporary Influence of South African Biometrics', Africa, 80, 5 (2010), pp. 642-662.
} 


\section{The Will to Standardise}

As apartheid ended in the early 1990s, an insidious danger lurked in the governing structure of post-apartheid South Africa. Provinces displayed a high degree of variability in their processes, technologies, and adeptness. To a significant degree, the quasi-independent homelands lacked competent bureaucracies and were riddled with corruption. In 1984, welfare was designated an "own affair" within the tricameral parliament, resulting in 'the creation of costly and duplicated administrative structures, with 13 "national" and 4 provincial head offices, plus another 3 coordinating departments'. ${ }^{18}$ Not only did the quality of service differ wildly, fundamental definitions of, say, what counted as disability meant that applicants may qualify for a grant in one province, but not if they move to another. ${ }^{19}$

The story was similar with regard to population registration. Despite the panoptic ambitions of the apartheid government, the basic task of population registration was split between more than 'a dozen discrete yet overlapping and duplicated population registers'. ${ }^{20}$ The system's weakness began with a lack of commitment to the registration of births: the Medical Research Council estimated that in 1994, less than one-fifth of births were registered within their first year. ${ }^{21}$ Registration and identification was particularly onerous for Africans, not least because of the unclear and competing structure of 'traditional', 'homeland', and national political authorities. Access to social grants before 1995 required proof of identity, citizenship (or permanent residence), and age. A range of documents - including national ID books, reference books, passports, homeland travel permits, or 'Farm Labourer' stamps - were variously used, but so were less formal systems, such as memories of 'the Great War' or 'the

\footnotetext{
${ }^{18}$ F. Lund, Changing Social Policy: The Child Support Grant in South Africa (Pretoria, HSRC Press, 2008), pp. $10-11$.

${ }^{19}$ Reddy and Sokomani, Corruption. See also G. Kelly, 'Regulating Access to the Disability Grant in South Africa, 1990-2013', CSSR Working Paper 330, 2013, http://cssr.uct.ac.za/pub/wp/330, retrieved 16 November 2014.

${ }^{20}$ K. Breckenridge, 'The Biometric state: The Promise and Peril of Digital Government in the New South Africa', Journal of Southern Africa Studies, 31, 2 (2005), pp. 267-282.

${ }^{21}$ F. Lund, 'Children, Citizenship and Child Support: The Child Support Grant in Post-Apartheid South Africa', in K. Breckenridge and S. Szreter (eds) Registration \& Recognition: Documenting the Person in World History (Oxford, Oxford UP, 2012).
} 
year of apartheid' to establish age. ${ }^{22}$ Put otherwise, methods of registration were implemented in uneven and uncoordinated manners.

During the transition, though, the system was understood to be woefully insufficient to meet the dual goals of rectifying racial discrimination and the accompanying social and economic inequality. As the government began in earnest to address the situation, it convened a series of national commissions of inquiry. Beginning in 1992, no less than five more major national commissions were convened. These commissions brought together an energetic coalition of academics, activists, and state officials who saw a reformed and expanded welfare program as a crucial project. In addition to parametric expansions, reformers sought to change the design of South African welfare to better reflect the realities of family structure and unemployment. $^{23}$

Their work reflected the solidifying politics of post-apartheid welfare, concerned primarily with improving the delivery of social protection while reducing fraud and corruption in the system. Although alternatives (such as significant delegation to the provinces) were at least considered, these initiatives rather quickly coalesced around an understanding of the problem as fragmentation that impeded service delivery and created the opportunity for mischief. Increased uniformity required a process of standardisation that, with time, was enacted through the administrative centralisation of social protection. The issue of identifying the recipients was at the forefront of these processes.

An early and influential source of this will to standardise was the 1996 Committee for Restructuring of Social Security, led by Thabo Mbeki's advisor Frank Chikane. The Chikane

\footnotetext{
${ }^{22}$ F. Lund, 'Children, Citizenship and Child Support'.

${ }^{23}$ Colonial and apartheid policies separated families and contributed to heightened unemployment, yet the inherited State Maintenance Grant assumed a nuclear family structure with a steadily employed (male) breadwinner. The designers of the new system sought to avoid these problems by mandating that the Child Support Grant should "follow the child" regardless of family situation. See F. Lund, Changing Social Policy, pp. 51-53.
} 
Committee was motivated by the belief that 'the delivery of social security is in crisis'. ${ }^{24}$ Fragmentation into fourteen separate systems, each with particular management, rules, and procedures, created the opportunity for loopholes 'which could easily be exploited by unscrupulous officials and members of the public.' Of the R11.5 billion paid out to 2.8 million beneficiaries in 1995-1996, it was estimated that about ten percent was lost to fraud and corruption. As it reports, 'fraud and corruption are rampant as a consequence of a lack of systems, proper internal controls, unduly complex legislation and department rules governing internal disciplinary proceedings.' This malfeasance is said to 'represent the greatest threat to the programme' of welfare, requiring a 'complete re-engineering'. ${ }^{25}$

While it mentioned the possibility that some tasks could be decentralised, this potential was not the subject of further detail; instead, the Committee focused on unifying and standardising a national system in which it was believed that the detection of fraud would be easier. The report also emphasised the need to establish 'linkages with other systems... such as the Home Affairs, Population Registration System, other pension insurance funds, South African Police Services (SAPS), Deeds Registry, the provincial financial control systems, and post offices and banks'. ${ }^{26}$ Specific recommendations for the social security system were offered, including a nationally organised system, a national human resources strategy, a standardised and integrated management system, a 'national transverse information system,' and regulatory simplifications. Thus, standardisation was a task both within social security and between other government programs.

This logic was directed particularly at the means of identifying grant recipients. The committee argued that the 'benefits of a biometric system can only be reaped if there is a

\footnotetext{
${ }^{24}$ CRSS, Report of the Committee for Restructuring of Social Security (Pretoria, Department of Welfare, 1996), p. 5.

${ }_{25}$ Ibid., p. 23.

${ }^{26}$ Ibid., p. 6.
} 
uniform system for the country as a whole'. ${ }^{27}$ They were deeply concerned that the Eastern Cape, Gauteng, Northern Province, KwaZulu Natal and Mpumalanga were in various stages of issuing biometric contracts, enrolling beneficiaries, and using different proprietary systems for delivery, perhaps permitting fraud: 'Without a national fingerprint database this gives no assurance that the person is who they claim to be.' Thus, their opposition to biometrics was pragmatic, concerned with the difficulty of creating a functioning system, especially as the amalgamation of different systems could compound data errors.

They were also deeply concerned with the costs, especially in light of early indicators of ineffectiveness and corruption. As early as 1993, biometrics were tested in the Cape Province but the results included considerable false positives. Despite this, biometrics reportedly cost more than double alternative means. In the Western Cape, the biometric system was said to cost R1.9 million per month, compared to the R16,500 per month savings from identifying duplicate recipients. ${ }^{28}$ Throughout, there were emerging concerns about corruption in provincial tendering for biometric welfare systems; ultimately these concerns would result in a full investigation by the Office for Serious Economic Offenses (OSEO) and ensnarl the NP's senior welfare official, Abe Williams. ${ }^{29}$

In the years following the Chikane Committee, the depiction of the problem and solution solidified into a relatively consensual view that (a) a crisis existed and (b) standardisation was the necessary response. The archive yields few dissenting voices. The 1997 White Paper on Social Welfare declared that fragmentation led to 'gross inefficiencies' and 'loopholes... which could be exploited by officials and the public'. ${ }^{30}$ The 'manual system' for accounting and 'the lack of an integrated national ID system' were specifically cited as

\footnotetext{
${ }^{27}$ Ibid., p. 44.

${ }^{28}$ Ibid., p. 67

${ }^{29}$ E. Cameron and F.D.J. Brand, Minister of Finance v Gore NO, (Pretoria, The Supreme Court of Appeal, 2006), available at: http://www.justice.gov.za/sca/judgments/sca_2006/2006_230.pdf, retrieved 16 November 2014.

${ }^{30}$ CRSS, Report, p. 51.
} 
problems. 'A uniform social grants system', it reasoned, required 'the rationalisation of computer systems and the development of a National Social Grants Register and automated fingerprint technology, ${ }^{31}$ It noted that a national re-registration effort might be required to produce an accurate database.

The sense of calamity was exacerbated by a prominent 1997 revelation from the Mail $\mathcal{E}$ Guardian newspaper that an estimated R1 billion was being lost to pension fraud from an annual budget of R14.3 billion. ${ }^{32}$ A major report in the following year from a government watchdog, the Public Service Commission (PSC), detailed the state of service delivery and proposed a variety of institutional and technical reforms. The PSC's Investigation into the Delivery of Social Security Services argued, like its predecessors, that the troubles of the social security program were the result of a lack of standards in the data captured from applicants, the complexity of regulations, the 'varying interpretations of eligibility,' and the methods of payment. It recommended the 'development of a national policy to standardise' paperwork, bureaucratic procedures, and identity documents. ${ }^{33}$ Further, it promoted increased centralisation of the welfare bureaucracy, rejecting a decentralised model where 'each province develops its own social security service' due to limited accountability and the recognition that 'all citizens of South Africa should be treated equally'. ${ }^{34}$

When the report received additional attention at a series of Parliamentary hearings in February and March 1998, many of the findings and arguments were affirmed. For example, members of the Executive Councils from Free State and the Eastern Cape complained of the identification troubles facing their provinces. In the Free State, it was alleged that citizens from Lesotho claimed South African pensions; in the Eastern Cape, former Transkei and

\footnotetext{
${ }^{31}$ Ibid., p. 54.

${ }^{32}$ T. Reddy and A. Sokomani, Corruption and Social Grants in South Africa (Cape Town, Institute for Security Studies, 2008), p. 19.

${ }^{33}$ PSC, Investigation into Social Security Services (Pretoria, Public Service Commission, 1998), p. ix.

${ }^{34}$ Ibid., p. 12.
} 
Ciskei citizens lacked the new ID books while others had both the new ID books and older identity documents that were still accepted, thus were able to benefit twice. ${ }^{35}$

The 2002 Report of the Committee of Inquiry into a Comprehensive System of Social Security for South Africa (led by Viviene Taylor) provided an important boost to these recommendations by advocating for the establishment of the South African Social Security Agency - an entity introduced in 2004. The goal of SASSA is to serve as 'the sole agency that will ensure the efficient and effective management, administration, and payment of social assistance ${ }^{36}$ As Selwyn Jehoma, the head of grants for the Department of Social Development, told Parliament in February 2003, in addition to providing clear accountability, integrating social security within a national agency would permit 'standardisation and uniform business processes' which would 'reduce costs of service delivery. ${ }^{37}$ Further, '[p]ractices of double dipping into funds would also not be possible with an Agency as the institution would have a better grip on social services.' Social Development Minister Skweyiya reiterated this, saying that 'financial leaks had necessitated the centralisation of control and payment of grants, leading to the formation of a social security agency that would do the job' ${ }^{38}$ As Mr. Jehoma told Parliament a few months later, this was necessary because 'it was not possible to give all nine provinces a set of guidelines and expect them to interpret and implement them in the same way [so] a nationally guided process was needed. ${ }^{39}$ While few in Parliament advocated otherwise, at least some civil society organisations were skeptical of the centralisation: the

\footnotetext{
${ }^{35}$ C. Saloojee, 'Minutes of the Portfolio Committee on Welfare', Parliamentary Monitoring Group, available at http://www.pmg.org.za/minutes/19980309-social-security-discussion-provincial-mecs, retrieved 6 February 2014.

${ }^{36}$ V. Taylor, Transforming the Present, Protecting the Future: Consolidated Report of the Committee of Inquiry into a Comprehensive System of Social Security for South Africa (Pretoria, Department of Social Development, 2002).

${ }^{37}$ S. Jehoma, 'National Social Security Agency Briefing', Social Development Portfolio Committee (February 2003), available at http://www.pmg.org.za/minutes/20030225-national-social-security-agency-briefing, retreived on 6 February 2014.

${ }^{38}$ H. Radebe, 'Minister Warns on Social Benefit Fraud', Business Day (1 March 2005), available at: http://allafrica.com/stories/200503010255.html, retrieved on 6 February 2014.
} 
Black Sash worried that SASSA would merely 'replicate the existing dysfunctions of the system' and that 'the new system overlooks the political, social and technological nuances in each province'. ${ }^{40}$ Their protest, though, was ineffectual.

SASSA, then, has been tasked with homogenising the policy and implementation of grants. While the fragmentation was particularly troubling for the manner in which it facilitated illicit behaviour, it was also at odds with the egalitarian ethos of the newly democratic nation. In the context of hard-fought equality, the grants, then, became a means of aspiring to and establishing uniformity of citizenship.

\section{The Pursuit of Objectivity}

In addition to bureaucratic structures, fragmented and discretionary practice has come under scrutiny. This section examines the manner in which everyday practices were problematized as a 'crisis' that justified biometric identification. As the second underlying force of the biometric imaginary, the pursuit of objectivity has sought to implement procedures and techniques that minimize the opportunity for subjective practice. In particular, techniques of objectivity have been directed at two forms of behavior that have continued to trouble the bureaucratic and policy elite: illicit access to grants and inappropriate or inept bureaucratic action.

Historically, grant fraud has occurred in various ways, from a 2008 case where just three people absconded with R22 million ${ }^{41}$, to more everyday acts of dissimulation, such as 'looking poor' to pass the means test. ${ }^{42}$ In conversations with and public statements by SASSA officials, two practices are considered particularly widespread. First, there is concern about

\footnotetext{
${ }^{39}$ S. Jehoma, 'Draft Social Security Agency Bill Briefing', Social Development Portfolio Committee (May 2003), available at http://www.pmg.org.za/minutes/20030520-draft-social-security-agency-bill-briefing, retrieved on 6 February 2014.

40 V. Robinson, 'Grants Agency "No Panacea", Mail \& Guardian (8 April 2005), available at http://mg.co.za/article/2005-04-08-grants-agency-no-panacea, retrieved 6 February 2014.

${ }^{41}$ M. Zulu, 'Three in Court for Defrauding the State Social Security Agency of Millions', City Press (3 February 2008).
} 
'phantom twins,' the practice of registering fictional children in order to receive extra grants (one town reportedly had more than 100 twins in 2010). ${ }^{43}$ Secondly, there is a perception that deceased pensioners are not reported as dead, and relatives continue to collect money on their behalf. This form of fraud is often linked to the use of bank accounts, where money is traditionally deposited without verifying that the recipient is alive. ${ }^{44}$

The wayward behavior of middle- and low-level bureaucrats has also been particularly troubling, with the widespread belief that error and incompetence undermine the effectiveness and equality of service. For pro-poor civil society organisations, bureaucrats have historically been found to be an impediment to the goal of improving legitimate access to the grants. This was most evident during the early years of the Child Support Grant when organisations like the Children's Institute and Black Sash highlighted 'worrying... reports that applicants are often dissuaded from persisting with applications because of the attitude of welfare officials. ${ }^{45}$ They called for 'welfare officials... to be educated' to improve their delivery behavior. As Simon Kimani of the National Association of Democratic Lawyers told Parliament, 'some welfare officials are arrogant, rude and abusive. ${ }^{46}$ At the time in 2002, the process of applying for grants was described as 'torturous' because there were 'no uniform standards, assessment guidelines and procedures, and some officials themselves [did] not know of or understand the procedures' ${ }^{47}$ For some, outsourcing to private payment firms was particularly problematic

\footnotetext{
${ }^{42}$ S. Plagerson, T. Harpham and K. Kielmann, 'Cash Transfers and Citizenship: Evidence from South Africa', The Journal of Development Studies, 48,7 (2012), pp. 969-982. A. Versfeld, 'AllPay and No Work: Spheres of Belonging Under Duress', (MA thesis, University of Cape Town, 2012).

${ }^{43}$ S. Piloso, “'Phantom Twins" Scam Exposed', Sunday Times (26 September 2010).

${ }^{44}$ Interview with informant \#6, a current government official (November 2012).

${ }^{45}$ T. Guthrie and L. Footner, Issue Paper on Social Security for Children in South Africa, The Child Health Policy Institute and Black Sash (July 2000), p. 18.

${ }^{46}$ S. Kimani, 'Social Security Delivery: Reports by Black Sash and NADEL', Welfare Portfolio Committee, available at: http://www.pmg.org.za/minutes/20000516-social-security-delivery-reports-black-sash-nadel, retrieved 6 February 2014.

${ }^{47}$ T. Guthrie, 'Family Social Security Benefits in South Africa', Social Dynamics, 28, 2 (2002), pp. 122-145.
} 
due to the inability or unwillingness of private firms to provide quality services. ${ }^{48}$ As Francie Lund and colleagues noted, 'administrative discretion appears to be subverting the aim of the broader social policy.' ${ }^{49}$

The work environment has exacerbated these problems. Offices were poorly maintained. Electricity and other infrastructures were missing. Paperwork and documents have been particularly troubling, with necessary forms variously lost, in the wrong language, and open to forgery. ${ }^{50}$ For post-apartheid welfare, the documentary-mediation of state and citizen has often been a source of discretion and error, undermining the aspirations to fixed objectivity pinned upon them. ${ }^{51}$ During the 1990s, there was 'no way of verifying the authenticity' of applicants' documents, especially if they were issued by entities with which the welfare administration had little interoperability (most importantly Home Affairs). ${ }^{52}$ In 2001 , a report from the Auditor-General found 225,471 computer-generated ID numbers. These were formally supposed to be used for recipients who only had the apartheid-era identity documents, but in practice were used by unscrupulous bureaucrats to create false recipients. Nearly a decade later, an audit of SASSA highlighted similar documentary problems, noting deficiencies 'including information technology controls' and 'poor-filing management'. 53

For beneficiaries, a lack of identity documents has been one of the primary barriers to accessing the grants. Budlender et al. detail how 'officials were requiring documents and other

\footnotetext{
${ }^{48}$ N. Overy and R. Zuma, 'The Outsourcing of Social Security Grants in the Eastern Cape: Service Delivery Challenges and the Problem of Accountability', Public Service Accountability Monitor (2004), available at http://www.psam.org.za/research/1183035633.pdf, retrieved 6 February 2014.

${ }^{49}$ F. Lund, M. Noble, H. Barnes, and G. Wright, 'Is There a Rationale for Conditional Cash Transfers for Children in South Africa?', Transformation, 70, 1 (2009), pp. 70-91.

${ }^{50}$ S. Kimani, 'Social security delivery'.

${ }^{51}$ Although it is not traditional to consider inanimate paperwork an influential mediator, a growing amount of scholarship has emphasised the vitality of mundane artifacts. 'Just as discourse has long been recognised as a dense mediator between subjects and the world, we need to see graphic artifacts not as neutral purveyors of discourse, but as mediators that shape the significance of the linguistic signs inscribed on them,' writes M. Hull, Government of Paper: The Materiality of Bureaucracy in Urban Pakistan, (Berkeley, CA, University of California Press, 2012), p.13.

${ }_{53}^{52} \mathrm{PSC}$, Investigation.

${ }^{53}$ M. Hlongwa, 'Department of Social Development 2009/2010 Audit Report: Auditor-General's Briefing', Social Development Portfolio Committee (October 2012), available at http://www.pmg.org.za/report/20101012auditor-general-200910-auditor-generals- report-department-social-deve, retrieved 6 February 2014.
} 
evidence far beyond what the law dictated ${ }^{54}$ Early in the Child Support Grant this was recognised as a barrier, and lobbying removed some of the requirements for children but it still took a lawsuit - only decided in 2008 - to permit a broader array of documents, including sworn affidavits. ${ }^{55}$ Yet a 2010 survey found that problems with documentation remained the most significant reason for not receiving legitimate grants. ${ }^{56}$

As Breckenridge noted, biometrics remove bureaucracy 'from the world of paperbased documents and - more importantly - from the domain of human agency'. ${ }^{57}$ In Daston and Galison's words, 'Instead of freedom of will, machines offer... freedom from will. ${ }^{95}$ In the case of post-apartheid welfare, the goal continues: in a recent outline of work for 2012-2015, SASSA emphasises that 'The automation of systems for improved service delivery is nonnegotiable... The constant use of manual systems not only limits the number of applications that can be processed in a day, but also contributes significantly to fraud and corruption in the grants administration system' ${ }^{59}$

There is in South Africa a certain consistency in the welfare policy discourse. Since the 1990s, the social grants have been depicted as 'in crisis' due to the specter of these forms of bedeviling discretion. The illegal and diffuse nature of this behaviour makes estimating the extent of the problem quite difficult, but numerous entities have tried. ${ }^{60}$ These figures filter through Parliamentary hearings and budget speeches, news reports and opinion pieces, and daily discussions in South African society. When the Democratic Alliance said in Parliament that

\footnotetext{
${ }^{54}$ D. Budlender, P. Proudlock, and L. Jamieson, Developing Social Policy for Children in the Context of HIV/AIDS: A South African Case Study (Children's Institute, Cape Town, 2008), p. 17.

${ }^{55}$ F. Lund, Changing Social Policy, p. 75, 486.

${ }^{56}$ M. Leibbrant, I. Woolard, A. Finn, and J. Argent, 'Trends in South African Income Distribution and Poverty since the Fall of Apartheid', OECD Social, Employment and Migration Working Papers, 2010.

${ }^{57}$ Breckenridge, 'Biometric State', p. 281.

${ }^{58}$ L. Daston and P. Galison, 'The Image of Objectivity', Representations, 40 (1992), pp. 81-128.

59 SASSA, Annual Performance Plan for Fiscal Years 2012/13-2014/15 (Pretoria, South African Social Security Agency, 2013).

${ }^{60}$ Reddy and Sokomani, 'Corruption'.
} 
the DSD was 'crippled by managerial dysfunction' and facing 'a management crisis ${ }^{, 61}$ or when the Inkatha Freedom Party labeled 'all SASSA offices across the country as ... breeding grounds for corruption ${ }^{62}$, their rhetoric was not particularly uncommon, nor was it merely opposition politicking. The leaders of DSD and SASSA are also quick to admit widespread fraud and corruption, with Minister Dlamini calling it 'endemic' ${ }^{63}$ Despite the difficulties of accurately assessing the amount of fraud and corruption, the ambiguity is rarely noted. It is the perception of crisis that is productive - based on, but not congruent, with facts.

\section{South African Biometric Welfare under SASSA}

Janet Roitman has called for an understanding of "the kinds of work the term "crisis" is or is not doing'. ${ }^{64}$ In this case, at least one result is the adoption of biometric identification, conceived as a way to deliver grants impartially and uniformly, lowering costs and boosting efficiency. As a standard and objective technology, biometrics are understood as the solution to crisis. The 2012 contract and re-registration into a centralised biometric database is the high-water mark of the welfare administration's adoption of biometrics. In part, it was propelled by the weakness in national identification infrastructure. In the 1990s, welfare policymakers began promoting the Home Affairs National Identification System (HANIS) as a key enabler of welfare expansion. ${ }^{65}$ Its proponents meant HANIS to be a multipurpose

\footnotetext{
${ }^{61}$ M. Waters, 'Dept. of Social Development Crippled by Managerial Dysfunction', Democratic Alliance (2013), available at http://goo.gl/Sx2fVl, retrieved 6 February 2014.

${ }^{62}$ Inkatha Freedom Party, 'The Department of Social Development Must Root Out Fraud and Corruption in All SASSA Offices', (Durban, Inkatha Freedom Party, 2013), available at http://allafrica.com/stories/201303041828.html, retrieved 6 February 2014.

${ }^{63}$ SASSA, Annual Report 2011/2012 (Pretoria, South African Social Security Agency, 2012).

${ }^{64}$ J. Roitman, Anti-Crisis (Durham, NC, Duke University Press, 2013), p. 3.

${ }^{65}$ See PSC, Investigation; V. Taylor, Transforming the Present; and BIG Coalition, 'Submission to the Portfolio Committee on Social Development on the Consolidated Report of the Committee of Inquiry into a Comprehensive Social Security System for South Africa', Parliamentary Monitoring Group, available at http://www.pmg.org.za/docs/2003/appendices/030609BasicCoalition.htm, retrieved 6 February 2014.
} 
national identity card; however, it is a long-running fiasco that only began to issue identity cards in mid-2013. ${ }^{66}$

Instead, welfare officials began to take steps to develop a uniform identification method for grant recipients in particular. As early as 2003, a senior DSD official told Parliament that the proposed SASSA 'would not have nine different contractual arrangements across all the provinces'. ${ }^{67}$ In 2007, shortly after its formation, SASSA tried to standardise payment and identification infrastructure through a tender whose intent was 'to ensure that service providers appointed in the nine provinces provided a standardised payment service in line with the norms of service delivery approved by government ${ }^{, 68}$ It was ultimately (and begrudgingly) cancelled because no such regularity was deemed possible from the bids received. As the adjudication committee wrote, the bids did not offer 'standardised payment services,' appropriate norms and standards of security and integrity, nor were they costeffective. ${ }^{69}$ In the interim, SASSA used the inherited provincial systems, many of which were technically incompatible and ineffective. Furthermore, for technical and contractual reasons, SASSA has not had ownership of a unified biometric database for recipients. ${ }^{70}$ The system that resulted from the amalgamation of provincial databases has been routinely criticised for being out of date, filled with inaccuracies, and open to fraud. Where fingerprint verification did occur, it was not always reliable, such as the case in 1999 when one town was found to be home to 1,650 identical fingerprints. ${ }^{71}$

\footnotetext{
${ }^{66}$ Breckenridge, 'The Elusive Panopticon'. C. Hoag, 'The Magic of the Populace: An Ethnography of Illegibility in the South African Immigration Bureaucracy', PoLAR: Political and Legal Anthropology Review, 33, 1 (2010), pp. 6-25.

${ }^{67}$ S. Jehoma, 'Draft Social Security Agency Bill Briefing'.

${ }^{68}$ SASSA, 'Request for Proposals: Social Grant Payment Contractor', (Pretoria, South African Social Security Agency, 2007).

${ }^{69}$ N. Arendse, 'SASSA Bid Adjudication Committee Report Executive Summary', (Pretoria, South Africna Social Security Agency, 2008).

${ }^{70}$ Interview with informant \#2, a current government official (September 2012).

${ }^{71}$ C. Saloojee, 'Social Security Delivery Briefing', (Cape Town, Welfare and Population Development Portfolio Committee, 1999), available at http://www.pmg.org.za/minutes/19991109-social-security-delivery-briefing, retrieved 6 February 2014.
} 
More recently, though, biometrics have been turned inward as an effort to remove the opportunity for bureaucratic misbehaviour. As SASSA reported to Parliament in March 2010 when justifying their budget, '[s] taff were more strictly controlled through biometric access systems and clearer controls' that recorded employee activity to search for fraud and 'ensure that these staff could not easily access sensitive programs where they could manipulate information or create 'ghost beneficiaries' in the system'. ${ }^{72}$ This is part of a broader effort to automate grant delivery, removing unskilled or corrupt bureaucrats. For example, the acting CEO of SASSA illustrated the biometric imaginary's conception of objectivity in an early 2011 complaint that 'The lack of automated business processes make activities extremely labour-intensive and error-prone'. ${ }^{73}$ Later that year, the head of SASSA's internal audit and fraud management unit highlighted automation as a means of overcoming 'poor employee work ethic'. ${ }^{74}$ Moving to electronic systems also saves money, and the acting CEO of SASSA noted during a time of financial limitations that automation also helped lower personnel, their 'second largest portion of the budget'. ${ }^{75}$

The continuing salience of these twin goals is clearly evident in the issuance of the new grant payment contract in early 2012 to Netl CPS, a South African technology firm. The government sought to address the same issues as in the failed tender mentioned above. Its request for bids from contractors called for 'significantly improved services' with 'sameness of Beneficiary experience. ${ }^{9} 6$ 'The minimum acceptable requirement during bulk and on-going enrolment,' they said, 'is that all ten finger prints of Beneficiaries must be captured. The Biometric Data capturing during enrolment will be used for matching and authenticating

\footnotetext{
${ }^{72}$ C. Pakade, 'SASSA Budget and Strategic Plans', (Cape Town, Social Development Portfolio, 2010), available at http://www.pmg.org.za/report/20100309-south-african-social-security-agency-sassa-budget-strategic-plans, retrieved 6 February 2014.

${ }^{73}$ L. Ensor, 'Social Grant Agency Plans to Save R426m this Year', Business Day (16 February 2011).

${ }^{74}$ T. Sibanyoni, 'Thousands Convicted of Social Grant Fraud', Mail \& Guardian (6 October 2011).

${ }^{75}$ C. Pakade, 'SASSA Budget and Strategic Plans' (Social Development Portfolio Hearing, 2010), available at http://www.pmg.org.za/report/20100309-south-african-social-security-agency-sassa-budget-strategic-plans, retrieved on 6 February 2014.

${ }^{76}$ All government document quotations are sic.
} 
during payment process.' In addition to requiring this data from grant recipients, beneficiaries - such as children - would also be incorporated. The goal, it explained, was to ensure 'that a Beneficiary is not enrolled more than once'. ${ }^{77}$

The award in early 2012 of the R10 billion contract for the entire country to Net1 CPS prompted an acrimonious court challenge by a losing bidder, AllPay. ${ }^{78}$ As a subsidiary of ABSA bank, AllPay was the incumbent payment provider in the Western Cape, Free State, Gauteng and parts of the Eastern Cape, while Netl CPS operated in the other provinces (except Mpumalanga, where a third firm - Epilweni — was used). AllPay alleged improprieties in the tendering, including a potentially last minute change in requirements. These allegations were quickly supported by subsequent media reports that suggested the influence of bribery. ${ }^{79}$ As of late 2014, these assertions led to a brief investigation in South Africa, one ongoing in America (where Netl is listed on the stock exchange), and a series of lawsuits that came to the fore with a November 2013 decision by the Constitutional Court which required a new tender be offered without procedural irregularities.

SASSA's court filings in response to AllPay's initial February 2012 complaint make clear the importance of standardisation and biometric authentication to their new contract. Their filings reiterate the established understanding of delivery failure and abuse discussed above. For example, the SASSA representative explained, 'that the six different [payment] methodologies employed in the Eastern Cape Province has directly led to substantial fraud and other abuses. ${ }^{80}$

In contrast to SASSA's response, AllPay's complaint depicted a different vision for the contract. 'AllPay's focus,' they asserted, 'is to facilitate access to financial services and products

\footnotetext{
${ }^{77}$ SASSA, 'Bid for Provision of Payment Services for Social Grants', (Pretoria, South African Social Security Agency, 2011).

${ }^{78}$ Another bidder, Empilweni, also contested it, but lacked the resources to do so as meaningfully.

${ }^{79}$ C. McKune, 'Social Grant Contractor's Sideline Plan', Mail \& Guardian (9 September 2012), available at http://mg.co.za/article/2012-09-28-00-social-grant-contractors-sideline-plan, retrieved 6 February 2014.
} 
to beneficiaries of social grants, with particular focus on the rural and semi-urban communities'. ${ }^{81}$ Given the extensive network of ABSA bank branches and ATMs, AllPay maintained that they could provide formal financial services where the non-bank Netl could not. An insistence on biometric identification for each payment (instead of just registration) would render ATMs useless because they do not have fingerprint scanners. SASSA, however, rejected the preeminence of 'banking the unbanked,' contending that AllPay 'did not make provision for adequate biometric verification and standardisation of services' and thus 'fell short of requirements imposed by SASSA ${ }^{82}$

Net1 CPS, in contrast, put biometric identification at the core of its offerings, and, as they gleefully revealed in their submissions to the court, their new offering has been able to combine their proprietary biometric payment technology with the standard national payment system (such as that used by bank cards and ATMs). Because the standard system would still not allow fingerprint verification, Net1 CPS would 'conduct proof of life verification telephonically, as an alternative to fingerprint technology'. ${ }^{83}$ This new form of voice biometric verification would be used in cases where recipients were receiving their grants into a bank account, requiring a brief monthly call to certify they had not deceased. ${ }^{84}$

This seems to have caught AllPay by surprise. Not completely without merit, they had believed that fingerprinting was the biometric method de rigueur. Indeed, in declaring the contract invalid in late 2013, the Constitutional Court affirmed that a last-minute shift to requiring monthly biometric verification (rather than only at registration) rendered 'the

\footnotetext{
${ }^{80}$ R. Ramokgopa, 'First and Second Respondents' Fuller Answering Affidavit to Part 'A' of the Application', Case No. 7477/12 in the North Gauteng High Court of Pretoria (21 February 2014), p. 10.

${ }^{81}$ C. Webb, 'AllPay Founding Affidavit', Case 7477/12 in North Gauteng High Court of Pretoria (2012), p. 22.

${ }^{82}$ R. Ramokgopa, 'First and Second', p. 11.

${ }^{83}$ S. Belamant, 'Interim Answering Affidavit', Case 7477/12 in North Gauteng High Court of Pretoria (8 February 2012), p. 14.

${ }^{84}$ This is particularly relevant given a partnership with Grindrod Bank to provide bank accounts to grant recipients. For a discussion of the resulting controversy, see K. Donovan, "FFinancial Inclusion Means Your Money Isn't With You" - Conflicts Over Social Grants and Financial Services in South Africa', in Money at the Margins: Global Perspectives on Technology, Inclusion \& Design (forthcoming).
} 
process entirely uncompetitive'. ${ }^{85}$ It was not the case that AllPay was opposed to biometric identification - indeed, they spent considerable time detailing their technical acumen - but only after seeing their opening salvo in favour of 'banking the unbanked' stall. It was a difference in emphases arising from technical and institutional legacies; while both would conduct fingerprint enrolment to remove duplicate entries, Netl stressed a supposedly objective and standardised way to identify and pay recipients each month. Net1 CPS stakes its work on universal biometrics; for AllPay, it has been secondary to - even sometimes at odds with — its banking and ATM system.

Beyond the court filings, SASSA officials have validated the new system to the public. For example, in response to an inquiry about grant fraud from Parliament, the CEO of SASSA called the new biometric scheme 'the greatest risk reduction tool that SASSA had engaged in its history'. Emphasising the appeal of removing bureaucratic weakness, she has specifically highlighted 'automation of business processes. ${ }^{86}$ Subsequent statements and reports followed suit. ${ }^{87}$

As of late 2014, following the Constitutional Court's unanimous declaration that the contract between SASSA and Netl CPS was 'constitutionally invalid', where this proclaimed success stands, however, is less clear. ${ }^{88}$ The Court found that SASSA had contravened its constitutional duties in two ways during the tender process. First, the last-minute shift to seemingly requiring biometric verification at each payment created vagueness and uncertainty that undermined procedural fairness. Secondly, SASSA did not ensure that Net1 CPS was, as constitutionally required, empowering previously disadvantaged people. And while it thus found the contract 'fatally defective', it recognised the importance of continued grant

\footnotetext{
${ }^{85}$ J. Froneman, AllPay Consolidated Investment Holdings (Pty) Ltd and Others $v$ Chief Executive Officer of the South African Social Security Agency and Others, (Johannesburg, Constitutional Court of South Africa, 2013), p. 49.

${ }^{86}$ V. Peterson, 'SASSA Re-registration Progress \& Annual Report 2011/12', (Cape Town, Social Development Portfolio Committee, 2012).

${ }^{87}$ For example, SASSA, 'Annual Report 2012/2013'.
} 
delivery. ${ }^{89}$ Therefore, it required a new tender process be conducted with regular oversight by the judiciary.

For SASSA, the task of distributing millions of rand per month has required a sociotechnical network that minimises the capacity for intermediaries to serve as anything but passive infrastructures. In the words of the PSC, the goal is that 'policy and execution are not divorced. ${ }^{90}$ Biometric identification has been understood as a crucial means of doing so, serving as what Rose calls a 'key fidelity technique.'91 In many ways, the new grant payment and identification infrastructure instituted in 2012 is the result of nearly two decades of reform efforts. The Chikane Committee's call for biometrics to be addressed in a unified, national manner has been accomplished. In Minister Dlamini's words, 'The improved biometric-based payment solution was long overdue and will go a long way towards minimising fraud and corruption so prevalent in the previous systems. ${ }^{, 92}$ But if the literature on audit ${ }^{93}$ is an indicator, there will need to be a social solution to the lack of trust, for ones based on technique alone 'fail to immunise the assemblages they govern from doubt'. ${ }^{94}$ Indeed, already the biometric technology has been questioned and subject to fraud, such as a case where fraudsters were found to be in possession of three biometric registration machines. ${ }^{95}$ The rest of this paper shifts from this history to consider these shortcomings more directly.

\footnotetext{
88 J. Froneman, 'All Pay Consolidated', p. 53.

${ }^{89}$ Ibid., 'All Pay Consolidated', p. 41.

${ }^{90} \mathrm{PSC}$, Investigation.

${ }^{91}$ N. Rose, Powers of Freedom: Reframing Political Thought (Cambridge, Cambridge University Press, 1999), p. 155.

92 B. Dlamini, 'Statement by the Minister of Social Development, Bathabile Dlamini, on the Introduction of the New Biometric-Based Payment Solutions for Social Grants', Department of Social Development, available at http://www.dsd.gov.za/index.php?option=com_content\&task=view\&id=379\&Itemid=82, retrieved 6 February 2014.

${ }^{93}$ M. Power, The Audit Society: Rituals of Verification (Oxford, Oxford University Press, 1997).

${ }^{94}$ N. Rose, Powers of Freedom, p. 155.

${ }^{95}$ M. Jacobs, 'SASSA Seeks to Secure System', IT Web, available at http://www.itweb.co.za/index.php?option=com_content\&view=article\&id=68735:SASSA-seeks-to-securesystem\&catid=141, retrieved 6 February 2014
} 


\section{The Myth of Mimesis}

Policymakers and their peers in civil society, the news media, and elsewhere have presented biometrics as a material means of improving service delivery, uniformly identifying recipients, and removing undesirable activity. Speaking of the new biometric grants program, Social Development Minister Dlamini unequivocally stated that it 'will eliminate incidents of fraud and corruption in the social grants system' which she said resulted from the 'manual system that SASSA has been using. ${ }^{96}$ SASSA's chief, Virginia Peterson, claimed 'the new SASSA card... will make it virtually impossible for fraudsters to defraud the Agency. ${ }^{97}$ This appeal of biometric identification rests on its presumed uniqueness, universality, and its ability to labour reliably free of error. ${ }^{98}$

This faith in biometrics builds on the presumption of universality and algorithmic objectivity. This is considered especially so when compared to alternative means of authentication, such as PINs which are considered vulnerable to fraud because the number can be shared. In contrast to this view of imperviousness, Magnet argues that biometric failure is not an aberration or exception, but rather an endemic feature. ${ }^{99}$ The experience in South Africa adds to her thesis, suggesting the faith in biometrics is at least partly mistaken, that they are unable to remove the unevenness for which they are adopted. The mistake arises from a simplistic, overly technocratic understanding of the real-world implementation. Focusing too closely on the technical means through which individuals are identified by the state - rather than understanding the larger complexities of such an unwieldy task - often underlies the biometric imaginary. Even the otherwise thoughtful Chikane Committee fell prey to defining problems and solutions in terms of technological systems, arguing that the 'principle cause ...

\footnotetext{
${ }^{96}$ B. Dlamini, 'Statement', 2012.

${ }^{97}$ V. Peterson, SASSA 2011/2012 Annual Report (Pretoria, South African Social Security Agency, 2012).

${ }^{98}$ Influential supporters of biometric identification reflect similar sentiments, including M. Garcia and C.M.T. Moore, The Cash Dividend: The Rise of Cash Transfers in Sub-Saharan Africa (Washington, D.C., The World Bank, 2012), p. 7; A. Gelb and J. Clark, 'Identification for Development: The Biometrics Revoution', (Washington, D.C., Center for Global Development, 2013).

99 S. Magnet, When Biometrics Fail: Race, Gender, and the Technology of Identity (Durham, NC, Duke University Press, 2011).
} 
[of] serious and widespread' fraud and corruption was 'the lack of proper systems of internal control'. ${ }^{100}$ Such a view ignores the role that poverty, inequality, and limited opportunity have in generating fraud. ${ }^{101}$ Instead, it focuses particularly on reforming systems of surveillance and audit. Biometrics, here, become another technical solution to social problems. But as the repeated difficulties instituting such a system demonstrate, one cannot take heed of technical efficacy in isolation from the bureaucratic technopolitics of South Africa.

This false and narrow faith in biometrics has a lengthy pedigree in South Africa. ${ }^{102}$ It has continued today, even as problems emerged in the 2012-2013 registration initiative. For example, the children who were required to be enrolled often reacted negatively to the experience, protesting and crying. ${ }^{103}$ Elderly and disabled recipients found it difficult to travel to the registration sites. Early results from the use of the voice recognition system, too, suggest technical difficulties, including poor recording environments during re-registration and delayed implementation. ${ }^{104}$ The result is a chaotic and confused scene at payment locations, not a standardised process. ${ }^{105}$

A more significant failure of the biometric technology is the portion of the population that has been unable to enroll. In September 2013, thousands of elderly and ill pensioners did not receive their grant because they had been unable to re-register and promised home visits by SASSA had not occurred. ${ }^{106}$ Biometrics have proven especially problematic for domestic labourers whose fingerprints are eroded from years of washing dishes. Additional worries exist for farm and mine labourers, many of whom have lost fingerprints or even whole fingers and

\footnotetext{
${ }^{100}$ CRSS, Report.

${ }^{101}$ For a similar argument with regard to behavioral change and prepaid metering in South Africa and Britain, see A. Von Schnitzler, 'Traveling Technologies: Infrastructure, Ethical Regimes, and the Materiality of Politics in South Africa', Cultural Anthropology 28, 4 (2013), pp. 670-693.

${ }^{102}$ Breckenridge, 'Verwoerd's Bureau of Proof'; Breckenridge, Biometric State.

${ }^{103}$ Interview with informant \#6, a current member of government (November 2012).

${ }^{104}$ H. Kweyama, 'New SASSA System Infuriates Pensioners', IOL News (11 February 2013).

105 C. McKune, 'Another Red Flag Raised in Sassa Tender', Mail \& Guardian (2014), available at: http://goo.gl/HiKMC4, retrieved on 22 October 2014.

${ }^{106}$ Black Sash, 'The Black Sash Calls on SASSA to Urgently Assist Victims of Grant System Error', available at http://goo.gl/NmeZPD, retrieved 6 February 2014.
} 
hands. Because biometric identification is compulsory in the new system, these populations will require a procurator, an individual who will enroll and withdraw money on their behalf. ${ }^{107}$ In October 2012, with only 15 percent of the recipients re-registered, 13,000 procurators had been required. ${ }^{108}$ This creates a form of dependency that, at the very least, will introduce complicated negotiations and conflicts for the individuals. More fundamentally, it unsettles the stated goal of 'sameness of Beneficiary experience' ${ }^{109}$ Importantly, this disjuncture between presumed (and marketed) universality and the diverse reality of bodily features occurs along class, age, and gender lines: while fingers typical of white collar labor are rarely problematic, for low-income populations doing manual labor, this is not the case.

For all their mimetic aspirations, neither biometric technologies nor the dominant ways in which they are conceived accurately reflect reality. This is what makes the case of the biometric imaginary particularly apt: an imaginary is not a fantasy - it is grounded in reality and is actually productive - but it may be decoupled from certain on-the-ground realities. Put otherwise, despite biometric universality and objectivity being mythical, the biometric imaginary is productive. The technology does, viewed en masse, by and large enable an enormous and impressive welfare program. But like other technopolitical efforts, biometric identification can also be a productive failure. ${ }^{110}$ The promises embedded in the technology such as ending corruption - need not be fully realised in order to justify the expense and effort of biometrics. This interpretive flexibility enables a wider range of support for biometric identification, fueling the biometric imaginary. Because biometric technology is presumed to be effective it can serve certain needs.

\footnotetext{
${ }^{107}$ Interview with informant \#2, a current member of government (September 2012).

108 SASSA, Reregistration Process (Cape Town, Portfolio Committee on Social Development, 30 October 2012).

${ }^{109}$ SASSA, 'Bid for Provision'.

${ }^{110}$ See P. Edwards and G. Hecht, 'History and the Technopolitics of Identity: The Case of Apartheid South Africa', Journal of Southern African Studies, 36, 3 (2010), pp. 619-639.
} 
This was clear when Minister Dlamini was 'pleased to report' in March 2013 that the biometric re-registration process had resulted in 44 thousand grants being cancelled and 66 thousand lapsing due to non-collection. ${ }^{111}$ This was represented - both in her speech and the subsequent media reports - as a successful example of using biometric identification to, as she put it, 'root out fraud and corruption whenever and wherever it appears to ensure that social grants only go to eligible beneficiaries.' As a portion of beneficiaries (less than half a percent) this is quite small, but that does not seem to register.

An important fact is that welfare surveillance and auditing in the form of biometric identification did not need to prove technically efficacious in order to produce its effects here. These individuals were not caught, but rather preemptively canceled or let lapse their grants. Even if all the lapsed grants were fraudulent (an heroic assumption given widespread beneficiary confusion and frequent normal turnover), it was not the promised de-duplication or identity verification that was responsible. It was the perception that the technology functions which produced its result. The authoritative presentation of biometric technology as effective is performative; rupture-talk helps to create the desired disjuncture. ${ }^{112} \mathrm{~A}$ bit more speculatively, one can imagine that the presentation of such anti-corruption efforts - especially ones utilising innovative and not particularly well-understood technology - performs a different reality to another audience: it demonstrates a particular seriousness about the 'crisis' in grant fraud and corruption on the part of DSD and SASSA to a population and political elite deeply concerned with cost overruns and illicit grant access.

Finally, it is important to note another way in which biometrics 'work' even if they do not meet their promise of ending fraudulent access. In receiving the SASSA contract, Net1 CPS secured a large and lucrative market of around R2bn annually. Had they lost the

\footnotetext{
${ }^{111}$ B. Dlamini, 'Statement by the Minister', 2013.

${ }^{112}$ G. Hecht, 'Rupture-Talk in the Nuclear Age: Conjugating Colonial Power in Africa', Social Studies of Science, 32, 5-6 (2002), pp. 691-727. On this phenomenon in surveillance, see K. Gates, Our Biometric Future:
} 
contract, 50 percent of their business would have reportedly followed. ${ }^{113}$ Instead, they have revealed that they are currently in talks with 11 other countries, no doubt benefiting from the prestige and experience of this contract. Serving as payment provider for so many has also opened up ancillary markets, such as (controversially) offering financial services. ${ }^{114}$ For those who place credence in the corruption allegations (which they deny), the importance of this contract to the firm is taken as motive, but a more general point is also true: the fervent commitment to combating the 'crisis' with biometric identification - and not, say, identity documents - has boosted a nascent technology without many other markets.

\section{The Political Ambiguities of Delegation}

In addition to its means, the end results of this process are also worthy of questioning. The effort to end improper discretion and uneven service delivery has resulted in a situation where responsibility has increasingly been delegated away from humans and toward machines. This has primarily been twofold: (a) away from little scrutinised and poorly verified grant applications and toward interoperable databases in order to remove those deemed undeserving and (b) away from street-level bureaucrats and toward electronic cash dispensers. This transformation is widely considered legitimate, but in neither case is it an unalloyed good. Instead, as von Schnitzler has discussed with regard to prepaid metering in South Africa, these infrastructures implement particular ethical and political regimes. ${ }^{115}$ In the case of biometric welfare in South Africa, it may even be expanding the distance between the state and its most vulnerable citizens.

\footnotetext{
Facial Recognition Technology \& the Culture of Surveillance (New York, NYU Press, 2011) and J. Masco, 'Lie Detectors: On Secrets and Hypersecurity in Los Alamos', Public Culture 14, 3 (2002), pp. 441-467.

${ }^{113}$ A. Speckman, 'Net1 to Pump in Millions to Upgrade its Infrastructure to Distribute Social Grants', Business Report, available at http://www.iol.co.za/business/business-news/net1-to-pump-in-millions-to-upgrade-itsinfrastructure-to-distribute-social-grants-1.1232405\#.UZC2YKK111V, retrieved 6 February 2014.

${ }^{114}$ K. Donovan, “'Financial Inclusion Means Your Money Isn't With You”.

${ }^{115}$ A. von Schnitzler, 'Traveling Technologies'.
} 
The emphasis on technologies of surveillance and audit serves to constrict what Scott calls 'infrapolitics,' the everyday weapons of the weak. ${ }^{16}$ Such infrapolitics occurs in at least two ways. First, many poor South Africans share details on how to pass the means test and qualify for a grant. ${ }^{117}$ Condemning this as fraud ignores the dire situation of those who exist above the qualifying income but still in desperate need due to ongoing rampant underemployment. Second, many who at one point qualified for the grant continue receiving it after an improvement in their financial status; the Special Investigation Unit considers such behavior one of the primary forms of grant 'fraud'. ${ }^{118}$ Yet the simplistic, binary means test on which such reasoning relies ignores the fluid, fluctuating incomes of the poor. The dominant bureaucratic approach to fraud, then, ignores what are actually infrapolitical tactics and necessary livelihood strategies. ${ }^{119}$ Instead of recognising this, there are emerging suggestions from state officials of increasing the surveillance of grant usage, perhaps through digital transaction monitoring or payment systems that block certain purchases such as alcohol. ${ }^{120}$

As detailed above, the new grant system has sought to replace street-level bureaucrats with machines, as well as to increase recipient convenience by allowing payments at ATMs and third-party merchants (equipped with biometric readers). While 60 percent of beneficiaries used to receive their grant at SASSA pay points, as of April 2013, it had decreased to 22 percent, with a significant shift toward ATMs and retailers. ${ }^{121}$ Subsequently, ATM providers have reported 'a huge injection' of new users in the form of SASSA

\footnotetext{
${ }^{116}$ J. Scott, Domination and the Arts of Resistance: Hidden Transcripts (New Haven, Yale University Press, 1992). See also P. Chatterjee, The Politics of the Governed: Reflections on Popular Politics (New York: Columbia University Press, 2004) on the (anti-)politics of administration.

${ }^{117}$ S. Plagerson et al., 'Cash Transfers and Citizenship'; A. Versfeld, 'AllPay and No Work'.

118 S. Timm, 'New Biometric Card to Boot Out Social Grant Fraud', BuaNews (8 June 2012), available at http://www.allafrica.com/stories/201206090081.html, retrieved 6 February 2014.

${ }_{119}$ Moreover, it seems odd that fraud and corruption should be so closely linked when, in reality, they are different activities, often operating in different moral registers: a poor individual acting even poorer to get some assistance does not seem the same as a salaried government employee falsifying invoices, yet 'fraud and corruption' are so tightly linked discursively that the distinction is rarely made.

120 T. Monama, 'State to Take over Payments of Grants', IOL News, available at http://www.iol.co.za/news/politics/state-to-take-over-payment-of-grants-1.1572270\#.UnblKJR-TGC, retrieved on 6 February 2014.
} 
beneficiaries. $^{122}$ In contrast to the traditional SASSA pay points, where a government employee was present, in the new system, beneficiaries now interact with a third-party merchant or faceless machine.

The irony is that the distance between citizen and state has been extended in an effort to remove discretionary middle-men between the fiscus and the pockets of the poor. In Ferguson's felicitous phrase, the result is perhaps 'asocial assistance' rather than 'socially "thick" recognition... between state and citizen." ${ }^{23}$ When something fails - as it did during a technical error in January 2013 when many pensioners in the Western Cape did not receive their full grant - the delegation means those on the ground are unable to address the errors. ${ }^{124}$ The shift to objective technology is not neutral, for it biased toward those who control the technology.

These delegations and redistributions of power, in turn, raise the stakes elsewhere. The countless street-level negotiations, maneuvers, and deceptions that the biometric imaginary condemns as illicit fraud (rather than ambiguous infrapolitics) are minimised while the influence of the central policy and standards are enhanced. ${ }^{125}$ As discussed in section two, there has been a purposeful centralisation of policymaking, most notably through the creation of SASSA. This shift away from the autonomy of provinces and low-level bureaucrats has been considered an effort to reduce discretions that would introduce inequalities of service delivery; it is reflected in SASSA's desire for a singlularly defined delivery mechanism.

${ }^{121}$ D. Dunkerley, 'SASSA Biometrics Presentation at UCT Workshop on Social Protection', (Cape Town, Centre for Social Science Research, 2013).

122 A. Moyo, 'Social grant payments boost ATM transactions', IT Web (12 September 2013), available at http://www.itweb.co.za/index.php?option=com_content\&view=article\&id=67312, retrieved 6 February 2014.

${ }^{123}$ J. Ferguson, 'Declarations of Dependence: Labour, Personhood, and Welfare in Southern Africa', Journal of Royal Anthropological Institute, 19, 2 (2013), pp. 236.

${ }^{124}$ Interview with informant \#4, a member of civil society focused on human rights (March 2013).

${ }^{125}$ This can be compared to other social sectors, such as healthcare. E. Vale, "I Know this Person. Why Must I Go to Him?" Techniques of Authority Among Community Health Workers in Cape Town', Centre for Social Science Research Working Paper No. 314, 2012 and E. Vale, "You Must Make a Plan... or Some Story": Community Helath Workers' Reappropriation of the Care Manual', Center for Social Science Research Working Paper No. 312, 2012, has documented the improvisations necessary for community health workers to fulfill their duties, a street-level informality that is in conflict with official rules. A similar conflict is currently occurring with the qualifications for the disability grants, as more stringent rules exclude the needy. 
However, when the rise of biometric welfare administration is viewed as redistribution of subjectivity - rather than (as the biometric imaginary has it) an absolute reduction - then it is less surprising why the current biometric contract between SASSA and Netl CPS has been the subject of intense legal dispute and allegations of corruption. If true, it suggests that the effect of the biometric system has been to reduce petty corruption but increase grand corruption. ${ }^{126}$ Although SASSA and Netl strenuously deny the allegations (and have gone forward with the contract) the episode is an illuminating suggestion that the reduction of subjectivity at the street-level increases the subjectivity at the center. This centralisation also created a certain fragility, illustrated during the court battles when the judiciary found the contract invalid but refused to set it aside due to the disruption it would cause to the millions of grant beneficiaries.

Indeed, the centralisation of welfare decision-making in post-apartheid South Africa has created a situation of concentrated judgment about who qualifies for grants and who does not, both in policy and technical enactment. The opposition to street-level subjectivity magnifies the influence of decisions made by SASSA. Given the pathetic state of social assistance delivery at the end of apartheid, it seems clear that some centralised uniformity was necessary ${ }^{127}$ but numerous observers have argued that the South African state is too centralised and technocratic. ${ }^{128}$

The biometric imaginary may be understood similarly, but as I have argued, it is also the result of political liberalisation, an opening up that means no longer is poor administrative

\footnotetext{
${ }^{126}$ For scholars of the phenomenon, petty corruption refers to low-level bureaucratic bribes and misdeeds whereas grand corruption refers to "state capture" (purchase of laws and decrees by enterprises) as well as corruption in public procurement'. J. Hellman, G. Jones, D. Kaufmann, and M. Schankerman, 'Measuring Governance, Corruption, and State Capture: How Firms and Bureaucrats Shape the Business Environment in Transition Economies', World Bank Policy Research Working Paper No. 2313, 2000, p.4.

${ }_{127}$ M. Geviser, Thabo Mbeki: The Dream Deferred (Jonathan Ball, 2007), p. 716.

${ }^{128}$ Barchiesi, Precarious Liberation; H. Marais, 'The logic of expediency', in S. Jacobs and R. Calland (eds) Thabo Mbeki's World: The Politics and Ideology of the South African President (London, Zed Books, 2003); D. Hemson and M. O'Donovan, 'Putting Numbers to the Scorecard: Presidential Targets and the State of Delivery' in S. Buhlungu, J. Daniel, R. Southall, and J. Lutchman (eds) State of the Nation: South Africa 2005-2006 (Cape Town, HSRC Press, 2006).
} 
capacity free from the agitations and demands of the public. The technopolitical regime that reached its height with SASSA's 2012 biometric payment contract is closely tied to the founding principles upon which most agree: post-apartheid social policy should be equitably and competently administered, in a manner that is impersonal and objective, free from the informal and formal discriminations of the previous era.

\section{Conclusion}

The social grants are one of the flagship interventions of the new South Africa, even if, in many ways, they are the product of the old South Africa. This importance and their scale make the social grants the subject of politically divisive debates, ranging from their affordability to their impact. Throughout these contests, though, runs a commitment to delivering grants reliably and equitably. This realm of implementation is one of civil servants and paperwork, fingerprint ridges and accounting techniques. It is a complex interchange between the state and citizen that occurs millions of times each month. And it is a relationship to which biometric identification technology is pivotal.

On one level, this paper has been an exploration of the salience of biometric technology within the social grants program. What explains the investment in identification infrastructure by the welfare bureaucracies? Why this method and not others? A colloquial answer would point to fraud and corruption, and while the widespread belief that the grants are the subject of exploitation and administrative incompetence has been a key motivating factor, this does not exhaust the particular reasons and manners through which it has unfolded. Instead, my argument traces a shared commitment - the biometric imaginary - that has emerged and solidified during nearly twenty years of welfare implementation. This is not wholly distinct from the deeper history, but the emphasis on welfare provision is an important change that has facilitated the expansion. The biometric imaginary positions biometric technology as a necessary, suitable, and effective means of achieving standardised and 
objective welfare administration. It is broader than just the purchase and use of fingerprint scanners; it builds upon programs of institutional reform, policymaking debates, and infrastructural development. Yet, the implementation of a nationally centralised biometric identification scheme is perhaps its apogee, a technopolitical goal that has come together during the post-apartheid era as various forms of delivery weakness and fraud have bedeviled the initiative.

As I have traced, the institution of a national biometric grant identification scheme in 2012 has a long lineage. Most directly it is the result of SASSA's failed 2007 tender that was cancelled when no standardised option was deemed feasible. But the goal of a standardised and objective delivery mechanism is the result of a longer history, extending to at least the democratic transition where the inheritance of a fragmented bureaucracy curtailed the ability of the state to use its redistributive function to alleviate poverty. Unification through a process of centralised standards setting has been the order of the day, necessitating institutional reorganisation, regulatory alignment, and infrastructural interoperability. For the government, biometric identification represents an automated - and thus impersonal - means of identification, a way to end illicit behavior while paying grants uniformly. As I have argued, these commitments to standardisation and objectivity are deeply held, influencing welfare policy and practice beyond just biometric identification. As the new biometric grant system unfolds, they will continue to influence its trajectory, though unlikely in uniformly effective or positive manners.

\section{KeVIn P. DONOVAN}

Programs in Anthropology \& History and Science, Technology E Society, University of Michigan, Tisch Hall 1029, 435 South State St., Ann Arbor, MI 48109-1003.E-mail: kevinpd@umich.edu 